\title{
Mitochondrial DNA provides an insight into the mechanisms driving diversification in the ithomiine butterfly Hyposcada anchiala (Lepidoptera: Nymphalidae: Ithomiinae)
}

\author{
Alaine WHinNetT ${ }^{1,2}$, Keith R. WILlMOTT ${ }^{2,3}$, Andrew V.Z. BROWER ${ }^{4}$, Fraser SiMPSON $^{1}$, Marie \\ ZIMMERMANN $^{1}$, GERARDO LAMAS ${ }^{5}$ and JAMES MALLET ${ }^{1 *}$ \\ ${ }^{1}$ Galton Laboratory, 4 Stephenson Way, University College London, London NW1 2HE, UK \\ ${ }^{2}$ The Natural History Museum, Cromwell Road, London SW7 5BD, UK \\ ${ }^{3}$ The McGuire Center for Lepidoptera, Florida Museum of Natural History, University of Florida, Gainesville, FL, USA \\ ${ }^{4}$ Oregon State University, Corvallis, OR, USA \\ ${ }^{5}$ Museo de Historia Natural, Universidad Nacional Mayor de San Marcos, Lima, Peru
}

Keywords. Mitochondrial DNA, Andes, diversification, Ithomiinae, Hyposcada, mimicry, refuge hypothesis

\begin{abstract}
Geographic subspecies of several ithomiine butterflies on the lower east Andean slopes display a black and orange "melanic tiger" aposematic wing pattern that occurs from Colombia to Bolivia, while geographically adjacent lowland subspecies typically bear a coloured, "tiger" pattern. However, it is not clear whether subspecies with similar wing patterns in different regions have arisen through independent events of convergent adaptation, possibly through parapatric differentiation, or result from allopatric differentiation, as proposed by the refuge hypothesis. Here, we examine geographic patterns of divergence in the widespread and common ithomiine butterfly Hyposcada anchiala. We present phylogenetic hypotheses for 5 subspecies of H. anchiala, based on $1567 \mathrm{bp}$ mitochondrial DNA. All topologies indicated that a single switch in mimetic pattern best explained the wing patterning of the $H$. anchiala studied here. This finding suggests that the subspecies of $H$. anchiala studied here result from at least two stages of differentiation, and is consistent with a single colonisation into a novel altitudinal zone coincident with a wing pattern switch, followed by subsequent divergence within, rather than across altitudinal zones. The subspecies divergences indicated diversifications were consistent with the Pleistocene. Furthermore, the lowland subspecies were more recently derived than the montane taxa, in contrast to predictions of the "Andean species pump" hypothesis.
\end{abstract}

\section{INTRODUCTION}

Butterfly species richness reaches a global peak at the western edge of the Amazon basin and adjacent east Andean foothills (Robbins \& Opler, 1996). To date, however, there is little agreement on the main causes for this high diversity, and a number of competing hypotheses have been proposed. The Pleistocene forest refuge hypothesis (Haffer, 1969) has perhaps received the most attention (Brown, 1979, 1982, 1987; Hall \& Harvey, 2002; Sheppard et al., 1985), and indeed a number of east Andean lower elevation putative forest refugia have been identified (Brown, 1979, 1982). However, critics argue that parapatric differentiation across environmental gradients could produce similar biogeographic patterns (Benson, 1982; Endler, 1982). In particular, the rapid changes in both biotic and abiotic environments at the base of the eastern Andes could have helped generate the high species diversity in this region. Fjeldså (1994) went on to propose that Andean slopes act as a "species pump" for birds, where new species originate before subsequent dispersal into the Amazon lowlands.

The first studies of the effects of putative forest refugia on neotropical butterflies were based principally on two nymphalid subfamilies, the Heliconiinae and the Ithomi- inae (Brown, 1982, 1987). Both groups are notable for their members being unpalatable to predators and aposematically coloured, with often remarkable geographic differentiation in warning colour pattern. Heliconiines and ithomiines are extensively involved in Müllerian mimicry, in which two or more distasteful species converge on a common warning signal which is more easily learnt and remembered by predators (Müller, 1879). Theory predicts that Müllerian mimicry increases in value as the number of individuals displaying the warning signal increases, due to a lower rate of attack per individual.

Brown (1982) suggested that such species were likely to differentiate in isolated forest refugia because they are relatively sedentary and because random fluctuations in abundance of co-mimics could drive mimicry pattern change (Brown \& Benson, 1974; Joron et al., 1999). However, mimetic species are also expected to be highly susceptible to parapatric differentiation. Mimetic colour patterns also serve as mating cues (Jiggins et al., 2001), so shifts in mimicry pattern, which might be driven by geographic variation in abundance of co-mimics, are likely to disrupt gene flow. In the east Andean foothills mimetic butterfly faunas change rapidly over elevations of several hundred metres and distances of only a few

\footnotetext{
* Corresponding author; e-mail: j.mallet@ucl.ac.uk
} 


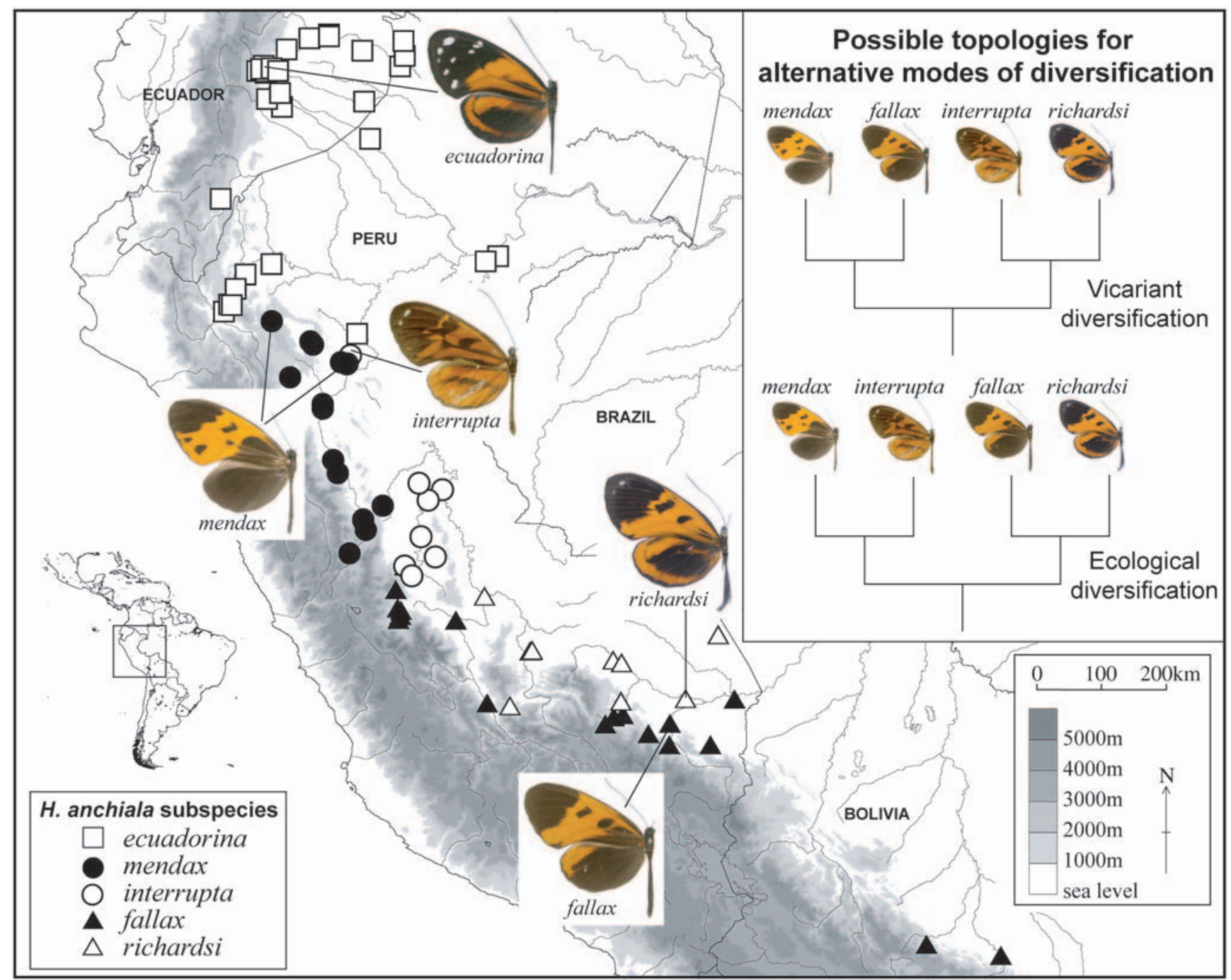

Fig. 1. Map showing the butterfly collection localities for H. a. mendax, H. a. fallax, H. a. interrupta, H. a. richardsi and $H$. a. ecuadorina. The lines connecting figured butterflies indicate sampling locations for the molecular samples. Inset shows two of the 26 possible rooted topologies for H. a. mendax, H. a. fallax, H. a. interrupta and H. a. richardsi.

kilometres (KRW pers. obs.), so the potential for colonisation of new mimetic environments is high.

This debate still remains today partly because of the difficulties in testing between vicariance or ecological adaptation as causes of divergence. Here, we examine the possible roles of these two causes in explaining divergence in a single west Amazonian ithomiine species, Hyposcada anchiala. The Ithomiinae (Lepidoptera: Nymphalidae) is an exclusively Neotropical subfamily which includes $\sim 355$ species (Lamas, 2004), all of which are thought to be highly unpalatable. These butterflies form part of multiple, diverse mimicry rings in a single location (Beccaloni, 1997a,b; Joron \& Mallet, 1998). Hyposcada anchiala occurs from eastern Panama to Bolivia and western Brazil, and contains 12 recognised subspecies (Lamas, 2004). These subspecies display wing patterns of two distinct mimicry complexes, the orange and black tiger (melanic tiger) complex and the tiger complex. These complexes are strongly altitudinally zoned, constrained to high altitude (submontane) and low altitude sites respectively. In this paper we focus on relationships between the submontane melanic tigers, $H$. a. mendax Fox from N. Peru and H. a. fallax (Staudinger) from S. Peru and Bolivia, and the geographically adjacent, lowland tiger-pattern subspecies, $H$. a. interrupta Tessmann in the north and H. a. richardsi Fox, in the south (Fig. 1.).

If individuals cluster by subspecies, there are 26 possible rooted cladograms for $H$. a. mendax, $H$. a. fallax, $H$. a. interrupta and $H$. a. richardsi. Of those, 6 are not informative about the associated mimetic-altitudinal shifts, for example an unresolved quadchotomy, 7 support just one mimeticaltitudinal shift, and 13 support two mimetic-altitudinal shifts. An example of the 7 topologies which support just a single shift in mimicry and altitude is a bifurcating topology, with both montane tiger melanic subspecies in one clade, and both non-melanic tiger, lowland subspecies in the other clade (as depicted in Fig. 1), this can best be explained by a vicariant diversification of two previously widespread ancestral populations. The other 13 topologies support two shifts of mimicry and altitude, and thus ecological diversification (Benson, 1982; Endler, 1982), an example is a sister pairing of the 
TABLE 1. Specimen information.

\begin{tabular}{|c|c|c|c|c|}
\hline Taxon & Voucher number & Collection locality & $\begin{array}{c}\text { Approximate collection } \\
\text { altitude }(\mathrm{m})\end{array}$ & $\begin{array}{c}\text { Genbank } \\
\text { accession }\end{array}$ \\
\hline H. anchiala interrupta & $02-512$ & $\begin{array}{l}\text { PERU: San Martín: km } 7.2 \text { Pongo- } \\
\text { Barranquita. } 06^{\circ} 17^{\prime} 20 \mathrm{~S}, 76^{\circ} 13^{\prime} 41 \mathrm{~W}\end{array}$ & 150 & DQ078355 \\
\hline H. anchiala interrupta & $02-2105$ & $\begin{array}{l}\text { PERU: San Martín: km } 7.2 \text { Pongo- } \\
\text { Barranquita. } 06^{\circ} 17^{\prime} 20 \mathrm{~S}, 76^{\circ} 13^{\prime} 41 \mathrm{~W}\end{array}$ & 150 & DQ078356 \\
\hline H. anchiala interrupta & $02-1293$ & $\begin{array}{l}\text { PERU: San Martín: km } 7.2 \text { Pongo- } \\
\text { Barranquita. } 06^{\circ} 17^{\prime} 20 \mathrm{~S}, 76^{\circ} 13^{\prime} 41 \mathrm{~W}\end{array}$ & 150 & DQ078312 \\
\hline H. anchiala mendax & $02-1644$ & $\begin{array}{l}\text { PERU: San Martín: Puente Serranoyacu. } \\
\qquad 05^{\circ} 40^{\prime} \mathrm{S}, 77^{\circ} 40^{\prime} \mathrm{W}\end{array}$ & 1150 & DQ078357 \\
\hline H. anchiala mendax & $02-1645$ & $\begin{array}{l}\text { PERU: San Martín: Puente Serranoyacu. } \\
\qquad 05^{\circ} 40^{\prime} \mathrm{S}, 77^{\circ} 40^{\prime} \mathrm{W}\end{array}$ & 1150 & DQ078358 \\
\hline H. anchiala mendax & $02-716$ & $\begin{array}{l}\text { PERU: San Martín: Puente Serranoyacu. } \\
\qquad 05^{\circ} 40^{\prime} \mathrm{S}, 77^{\circ} 40^{\prime} \mathrm{W}\end{array}$ & 1150 & DQ078359 \\
\hline H. anchiala mendax & $02-1602$ & $\begin{array}{l}\text { PERU: San Martín: La Antena. } \\
06^{\circ} 27^{\prime} 18 \mathrm{~S}, 76^{\circ} 17^{\prime} 54 \mathrm{~W}\end{array}$ & $800-1000$ & DQ078360 \\
\hline H. anchiala mendax & $02-2141$ & $\begin{array}{l}\text { PERU: San Martín: La Antena. } \\
06^{\circ} 27^{\prime} 18 \mathrm{~S}, 76^{\circ} 17^{\prime} 54 \mathrm{~W}\end{array}$ & $800-1000$ & DQ078361 \\
\hline H. anchiala fallax & $02-3519$ & $\begin{array}{l}\text { PERU: Madre de Dios: Mazuko. } \\
13^{\circ} 06^{\prime} \mathrm{S} 70^{\circ} 22^{\prime} \mathrm{W}\end{array}$ & 350 & DQ078477 \\
\hline H. anchiala ecuadorina & Ec 452 & $\begin{array}{c}\text { ECUADOR: Napo: Jatun Sacha. } \\
01^{\circ} 04^{\prime} \mathrm{S}, 77^{\circ} 36^{\prime} \mathrm{W}\end{array}$ & 450 & DQ078474 \\
\hline H. anchiala richardsi & G1 & $\begin{array}{l}\text { PERU: Madre de Dios: Río Los Amigos. } \\
\qquad 12^{\circ} 35^{\prime} \mathrm{S} 70^{\circ} 5^{\prime} \mathrm{W}\end{array}$ & 270 & DQ078475 \\
\hline H. virginiana & 8283 & $\begin{array}{l}\text { PANAMA: Cerro Campana. } \\
08^{\circ} 68^{\prime} 74 \mathrm{~N} 79^{\circ} 91^{\prime} 97 \mathrm{~W}\end{array}$ & $900-1000$ & DQ078476 \\
\hline H. zarepha flexibilis & 02-197 & $\begin{array}{c}\text { PERU: San Martín: Chumía. } \\
06^{\circ} 36^{\prime} 57 \mathrm{~S}, 76^{\circ} 11^{\prime} 10 \mathrm{~W}\end{array}$ & $300-450$ & DQ078362 \\
\hline
\end{tabular}

two subspecies from N. Peru (one montane, melanic and one lowland, non-melanic tiger), and a sister pairing of the two subspecies from S. Peru (one montane, melanic and one lowland, non-melanic tiger) (as depicted in Fig. 1.). Under this scenario, local processes drove the diversification of an ancestral N. Peru $H$. anchiala into two northern subspecies, a process paralleled independently in S. Peru.

Here, we use 1567 bp mitochondrial DNA (mtDNA) to reconstruct relationships within $H$. anchiala and examine whether resulting phylogeographic patterns are more consistent with expectations of geographic (vicariant) or ecological diversification.

\section{MATERIAL AND METHODS}

Genomic DNA was analysed from the four described $H$. anchiala subspecies, plus an additional non-melanic tiger pattern subspecies, H. a. ecuadorina Bryk. Outgroup taxa were chosen to represent two closely related species, $H$. virginiana (Hewitson) and H. zarepha (Hewitson), as determined by the sequencing of five Hyposcada species with two, independent nuclear regions, wingless and elongation factor 1-a (data not shown) as well as mtDNA data (Table 1).

A specimen of $H$. virginiana in $20 \%$ dimethylsulphoxide, $0.25 \mathrm{M}$ EDTA and saturated $\mathrm{NaCl}$ solution (DMSO solution) was identified and provided by Chris Jiggins (University of Edinburgh) and a dried specimen of $H$. a. richardsi was provided by GL. All other specimens were collected by the authors, preserved in DMSO solution, and identified to subspecies by GL and KRW. DNA was extracted from one third of the abdomen (H. a. richardsi) or one third of the thorax (all other specimens) using the DNAeasy kit (Qiagen, West Sussex, UK), according to the manufacturer's instructions, with an initial $3 \mathrm{~h}$ incubation at $55^{\circ} \mathrm{C}$, and a final elution volume of $300 \mu$ l. Genomic DNA extracts were preserved at $-20^{\circ} \mathrm{C}$. Dried wings were retained as vouchers at University College London, except for the $H$. a. richardsi and $H$. virginiana which were retained by the donors. PCRs were performed using primers Jerry and Pat (COI), or George and Imelda (COII) (Simon et al., 1994), in a $25 \mu \mathrm{l}$ volume, using $2 \mu \mathrm{l}$ template DNA under the following conditions: $1 \times$ PCR buffer, $0.6 \mathrm{mM}$ dNTPs, $4 \mathrm{mM} \mathrm{MgCl}_{2}, 0.5$ $\mu \mathrm{M}$ each primer, $0.025 \mathrm{U} / \mu 1 \mathrm{Taq}$, and $\mathrm{ddH}_{2} \mathrm{O}$, with an amplification profile of $94^{\circ} \mathrm{C}$ for $2 \mathrm{~min}$, followed by [COI: 4 cycles of $\left(94^{\circ} \mathrm{C}\right.$ for $45 \mathrm{~s}, 51^{\circ} \mathrm{C}$ for $45 \mathrm{~s}, 72^{\circ} \mathrm{C}$ for $\left.60 \mathrm{~s}\right)$ then 29 cycles of $\left(94^{\circ} \mathrm{C}\right.$ for $45 \mathrm{~s}, 51^{\circ} \mathrm{C}$ for $45 \mathrm{~s}, 72^{\circ} \mathrm{C}$ for $\left.90 \mathrm{~s}\right)$ ] or [COII: 33 cycles of $\left(94^{\circ} \mathrm{C}\right.$ for $45 \mathrm{~s}, 55.5^{\circ} \mathrm{C}$ for $45 \mathrm{~s}, 72^{\circ} \mathrm{C}$ for $\left.\left.90 \mathrm{~s}\right)\right]$ and a final $5 \mathrm{~min}$ extension at $72^{\circ} \mathrm{C}$. The $H$. a. richardsi sample proved difficult to amplify, probably due to its preservation with paradichlorobenzene (PDB), a chemical known to form covalent bonds to DNA. Weak H. a. richardsi PCR products were therefore excised from an agarose gel and incubated at $70^{\circ} \mathrm{C}$ for 10

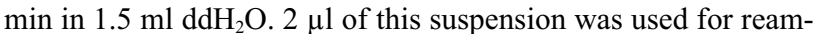
plification following the above protocol. Final PCR products were purified using the QIAquick PCR purification kit (Qiagen, West Sussex, UK), according to the manufacturer's protocol and sent to a commercial facility for cycle sequencing using the PCR primers, precipitation and sequencing.

Sequences were edited using SeqEd v1.0.3 (Applied Biosystems, Inc., Foster City, USA). PAUP version 4.0b 10 (Swofford, 2000 ) was used to calculate the numbers of variable and parsimony informative sites, and absolute and Hasegawa-Kishino- 
TABLE 2. Absolute pairwise distances for all H. anchiala individuals (below diagonal), mean HKY85 subspecies pairwise distances (in \%, above diagonal) and mean estimated time since divergence of subspecies [in years (y), to the nearest 5,000, above diagonal].

\begin{tabular}{|c|c|c|c|c|c|c|c|c|c|c|c|c|}
\hline & & \multicolumn{11}{|c|}{ Hyposcada anchiala subspecies and specimen number } \\
\hline & & \multicolumn{3}{|c|}{ interrupta } & \multicolumn{5}{|c|}{ mendax } & \multirow{2}{*}{$\begin{array}{c}\text { fallax } \\
02-3519\end{array}$} & \multirow{2}{*}{$\begin{array}{c}\text { ecuadorina } \\
\text { Ec } 452\end{array}$} & \multirow{2}{*}{$\begin{array}{c}\text { richardsi } \\
\text { G1 }\end{array}$} \\
\hline & & $02-512$ & $02-2105$ & $02-1293$ & $02-1644$ & $02-1645$ & $02-716$ & $02-1602$ & $02-2141$ & & & \\
\hline \multirow[t]{3}{*}{$i$} & $02-512$ & $\mathrm{X}$ & $\mathrm{X}$ & $\mathrm{X}$ & & & $\begin{array}{c}240,000 \mathrm{y} \\
0.55 \%\end{array}$ & & & $\begin{array}{c}140,000 \mathrm{y} \\
0.32 \%\end{array}$ & $\begin{array}{c}55,000 \mathrm{y} \\
0.13 \%\end{array}$ & $\begin{array}{c}85,000 \mathrm{y} \\
0.19 \%\end{array}$ \\
\hline & $02-2105$ & 0 & $\mathrm{X}$ & $\mathrm{X}$ & & & & & & & & \\
\hline & $02-1293$ & 0 & 0 & $\mathrm{X}$ & & & & & & & & \\
\hline \multirow[t]{5}{*}{$m$} & $02-1644$ & 9 & 9 & 9 & $\mathrm{X}$ & $\mathrm{X}$ & $\mathrm{X}$ & $\mathrm{X}$ & $\mathrm{X}$ & $\begin{array}{c}30,000 \mathrm{y} \\
0.72 \%\end{array}$ & $\begin{array}{c}285,000 \mathrm{y} \\
0.66 \%\end{array}$ & $\begin{array}{c}320,000 \mathrm{y} \\
0.74 \%\end{array}$ \\
\hline & $02-1645$ & 9 & 9 & 9 & 0 & $\mathrm{X}$ & $X$ & $X$ & $X$ & & & \\
\hline & $02-716$ & 7 & 7 & 7 & 6 & 6 & $X$ & $X$ & $X$ & & & \\
\hline & $02-1602$ & 9 & 9 & 9 & 2 & 2 & 6 & $\mathrm{X}$ & $X$ & & & \\
\hline & $02-2141$ & 9 & 9 & 9 & 0 & 0 & 6 & 2 & $X$ & & & \\
\hline$f$ & $02-3519$ & 5 & 5 & 5 & 12 & 12 & 8 & 12 & 12 & $\mathrm{X}$ & $\begin{array}{c}195,000 \mathrm{y} \\
0.45 \%\end{array}$ & $\begin{array}{c}220,000 \mathrm{y} \\
0.51 \%\end{array}$ \\
\hline$e$ & Ec 452 & 2 & 2 & 2 & 11 & 11 & 9 & 9 & 11 & 7 & X & $\begin{array}{c}140,000 \mathrm{y} \\
0.32 \%\end{array}$ \\
\hline$r$ & G1 & 3 & 3 & 3 & 12 & 12 & 10 & 12 & 12 & 8 & 5 & $X$ \\
\hline
\end{tabular}

Yano (HKY85) pairwise divergences (Table 2). The constancy of evolutionary rates across the tree was tested in PAUP with a likelihood ratio test, and a molecular clock calibrated as $2.3 \%$ sequence divergence per million years (Brower, 1994) was used to estimate divergence dates (Table 2). For comparison, Neighbour Joining (NJ), Maximum Parsimony (MP) and Maximum Likelihood (ML) analyses were performed in PAUP, and a Bayesian hypothesis was generated using MrBayes 3.0 (Huelsenbeck \& Ronquist, 2001), with H. virginiana, or H. zarepha, or $(H$. zarepha $+H$. virginiana) as the outgroup taxa. NJ trees were generated using HKY85 distances with random break ties, confidence in each node was assessed by performing 1000 rounds of $\mathrm{NJ}$ bootstrapping. MP topologies were conducted using a 10 replicate heuristic search with treebisectionreconnection (TBR) branch swapping, with random stepwise addition of sequences, support for clades was assessed by 1000 rounds of full heuristic bootstrapping with TBR branch swapping. ML trees were generated starting from random trees, using a heuristic search with TBR, random sequence addition, with the best fit model of sequence evolution $(\mathrm{HKY}+\mathrm{I}+\mathrm{G}$, by hLRT) and parameter estimates as identified by Modeltest 3.04 (Posada \& Crandall, 1998). Bayesian analyses were performed with parameters identified by Modeltest 3.04 (nst $=2$, rates $=$ invgamma), with four simultaneous chains run for $1,000,000$ generations, sampling a tree every 100 generations. Consensus trees with branch support in the form of posterior probabilities were derived from the final 9,000 trees (representing the final 900,000 generations), after confirmation that likelihood values had stabilised after the first 100,000 generations. All possible unrooted trees were generated and corresponding minimum evolution (ME) scores calculated, for one representative of each $H$. anchiala subspecies plus a $H$. virginiana outgroup, using distance settings.

\section{RESULTS}

Sequences up to $1611 \mathrm{bp}$ in length were successfully obtained from 13 individuals, representing five $H$. anchiala subspecies and two outgroup species (GenBank accession numbers DQ078312, DQ078355-62, and
DQ078474-77). To avoid problems associated with missing characters, sequences were edited to a final alignment covering the $1567 \mathrm{bp}$ region amplified in all specimens. The 1567 bp span 805 bp COI (alignment positions 1-805), 62 bp leucine-tRNA (806-867) and 700 bp COII (868-1567). Excluding the outgroup taxa, just 19 (1.21\%) sites were variable, 10 in COI and nine in COII, of which $11(0.70 \%)$ were parsimony informative. Of these 19 polymorphic sites, 16 differed in just one species (4 fixed and 5 polymorphic in $H$. a. mendax, 3 in $H$. a. fallax, 3 in $H$. a. richardsi, and 1 in $H$. a. ecuadorina), and three polymorphisms were shared; $\mathrm{C}$ in $H$. a. mendax + fallax, and $\mathrm{T}$ in $H$. a. ecuadorina + richardsi + interrupta; $\mathrm{G}$ in H. a. fallax + richardsi + interrupta, $\mathrm{A} / \mathrm{G}$ in $H$. $a$. mendax, and $\mathrm{A}$ in $H$. a. ecuadorina; and $\mathrm{A}$ in $H$. a. ecuadorina + richardsi + interrupta, $\mathrm{A} / \mathrm{T}$ in $H$. a. mendax, and $\mathrm{T}$ in $H$. a. fallax.

Absolute $H$. anchiala pairwise divergences (Table 2) ranged from 0 , within the $H$. a. interrupta or between $H$. a. mendax 02-1644, 02-1645 and 02-2141, to 12 between $H$. a. ecuadorina or $H$. a. richardsi and H. a. mendax 021644, 02-1645, 02-2141 and 02-1602. There was no significant rate heterogeneity among lineages of the clock enforced [ln likelihood 2487.286] and non-clock enforced [ln likelihood 2482.988] trees, suggesting the data conform to a molecular clock. Mean between subspecies divergence times were estimated using a mitochondrial clock (Brower, 1994) to between 55,000 and 320,000 years ago, for (H. a. interrupta $+H$. a. ecuadorina) and (H. a. mendax + H. a. richardsi) respectively.

Overall, the $H$. anchiala phylogenies had short internal branches and thus were quite poorly resolved. The clearest case of phylogenetic agreement between all reconstructions was the well supported recovery of the five $H$. a. mendax specimens as a monophyletic clade, for 


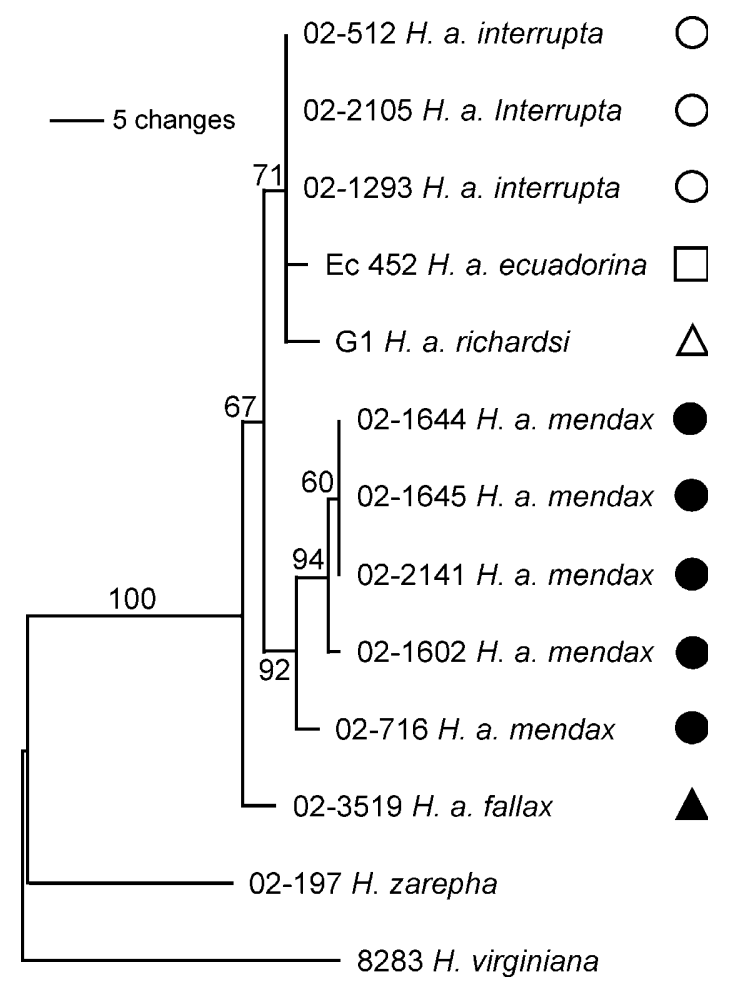

Fig. 2. Phylogenetic hypothesis inferred with maximum parsimony. Maximum parsimony bootstrap support values are given along branches. Subspecies symbols are as in Fig. 1., with filled symbols representing melanic butterflies.

example, in analyses using a $H$. virginiana $+H$. zarepha outgroup by bootstrap values of 94 (NJ) and 92 (MP), and a Bayesian posterior probability of 0.72 . Although the arrangements of $H$. anchiala differed both with outgroup used and reconstruction method, the topologies could be categorised into three, repeatedly generated types. NJ and MP analyses, using $H$. zarepha and $(H$. zarepha $+H$. virginiana) as the outgroup, shared a similar topology (as in Fig 2). All ML analyses and MP with a $H$. virginiana outgroup recovered the lowland $H$. anchiala as paraphyletic with regard to a sister pairing of $H$. a. mendax and $H$. $a$. fallax. The Bayesian analysis with a $(H$. zarepha $+H$. virginiana) outgroup shared a topology with NJ, MP and Bayesian analyses using just a $H$. virginiana outgroup (as in Fig 3). In addition, a fourth arrangement of a (H. a. mendax $-H$. a. fallax) and (H. a. richardsi $-H$. a. interrupta - H. a. ecuadorina) sister pairing was recovered once, by Bayesian analyses with a $H$. zarepha outgroup. In summary, of the four obtained topologies, two supported the lowland non-melanic $H$. anchiala having evolved from their montane melanic counterparts, one supported the vicariant hypotheses depicted in Fig. 1., and the other paired the montane melanic butterflies, but did not indicate their relationship to the non-melanic lowland $H$. anchiala. Although these arrangements differed in the direction of the wing pattern switch and altitudinal shift, all four topology types support the main finding that $H$. anchiala wing patterns can be most parsimoniously

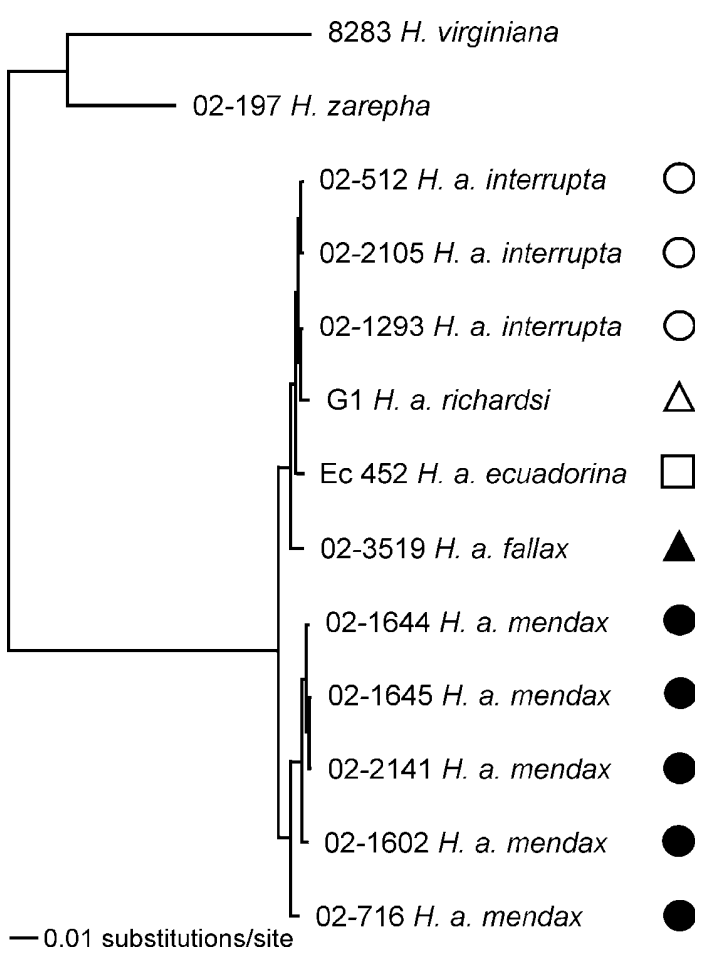

Fig. 3. Phylogenetic hypothesis inferred with Bayesian methods. 3 clades have Bayesian probabilities over 0.5: $(1644,1645$ and 2141), (1644, 1645, 2141 and 1602) and (1644, 1645, 2141, 1602 and 716) are supported with respective probabilities of 0.64. 0.85 and 0.72. Subspecies symbols are as in Fig. 1., with filled symbols representing melanic butterflies.

explained by a single switch in mimetic pattern and altitudinal range.

105 different trees were generated using distance settings, to represent all possible topologies. The mean ME score for those trees most parsimoniously explained by one mimetic pattern shift was $0.0429(\mathrm{n}=21$, range 0.0419-0.0445, median 0.0427) (the ME score of the topology which mirrored that recovered by $\mathrm{NJ}$ analysis was 0.0429), and the mean ME score for those topologies most parsimoniously explained by two shifts was 0.0439 $(\mathrm{n}=84$ range $0.0424-0.0454$, median 0.0439$)$.

\section{DISCUSSION AND CONCLUSIONS}

Despite the rapid substitution rate of mtDNA compared to most nuclear regions, sequence results yielded only low levels of divergence among $H$. anchiala subspecies. Tree reconstruction was compromised both by sequence invariance and possibly by the outgroup taxa assuming a position rather distant from the ingroup. Although tree reconstruction method, and use of $H$. virginiana, $H$. zare pha, or (H. zarepha $+H$. virginiana) as the outgroup affected ingroup arrangements, all the phylogenetic hypotheses were most parsimoniously explained by a single colour shift between melanic and nonmelanic taxa, thus the most recent radiations appear to be within altitudinal zones rather than between them. Taken along with the estimated subspecies divergences times, this finding is consistent with geographic diversification during the Pleistocene (11,000 - 1.8 Mya). This result of geographic 
divergence within an altitudinal zone parallels the findings by Willmott (2001) and Willmott et al. (2001) based on morphological phylogenies of Hypanartia Hübner (Nymphalinae) and Adelpha Hübner (Limenitidinae). In these genera speciation across elevational gradients occurred, but appeared relatively more difficult, infrequent and more typical of basal diversifications. The most common form of differentiation was speciation within or among montane regions. In contrast, in a recent study on Ithomiola Felder \& Felder (Riodinidae), Hall (in prep.) found multiple instances of parapatric differentiation up the sides of mountains. In Ithomiola, montane species in different regions are most closely related to adjacent species occurring at lower elevations, indicating that speciation across an altitudinal gradient is the rule in these butterflies.

Although theories of Neotropical diversification have tended to concentrate on taxa recognised as species, studies based on subspecies are also of great value as these taxa may often form an early stage in the diversification continuum that eventually leads to complete speciation. The subspecies divergences here (Table 2) suggest that the lowland taxa are more recently derived (H. $a$. richardsi $+H$. a. interrupta 85,000 y) than the montane taxa (H. a. mendax + H. a. fallax 310,000 y). Our finding of older montane taxa appears to contrast Fjeldså's (1994) reports that Andean bird species were, on average, younger than Amazonian species. Fjeldså went on to suggest that the Andes acted as a species "pump" producing novelties that were absorbed into the Amazon, which acted as a species "museum" However, a problem lies in just looking at taxa categorised (maybe incorrectly) as distinct species, and ignoring diversity at other (often lower) levels. For example, if the taxa regarded as young Andean species by Fjeldså were actually old subspecies, and the Amazon contained many, well-differentiated young subspecies (not recognised as being differentiated in species level analysis), the conclusions regarding the location of diversifications would be the exact opposite to Fjeldså's.

However, the data and phylogenetic hypotheses presented here must be interpreted with caution. Only the $H$. a. mendax clade is repeatedly well supported. Additionally, the topologies represent the mtDNA tree, which is not necessarily equivalent to the species tree, due to processes including horizontal transfer, introgression and ancestral polymorphism (Brower et al., 1996). Given that the five $H$. anchiala subspecies here diverged moderately to rapidly on an evolutionary scale (within the last 300,000 years) the internodal branches are short, increasing the chance that ancestral copies failed to coalesce before diversification and therefore reducing the likelihood that mtDNA reflects the true organismal phylogeny (Maddison, 1997). Additionally, there is evidence that introgressive gene flow may have considerably shaped the $H$. anchiala mtDNA topologies. Although distinguished by a mean pairwise divergence of $0.5 \%$ (corresponding to a radiation 220,000 years ago), intermediates are known between $H$. a. fallax and $H$. a. richardsi
(Lamas, pers. obs.). One intermediate is also known between $H$. a. fallax and $H$. a. interrupta. That these subspecies are capable of interbreeding introduces potential for introgressive gene flow. Even rare events can have a large impact, for example, an advantageous mutation could lead to a selective mtDNA sweep. Such gene flow can make two taxa appear to have diverged more recently than their actual original divergence time, creating a particular problem in studies, such as this, when the timing of the diversification event is critical for making inferences (Barraclough \& Nee, 2001).

To date, few studies have taken a phylogeographic approach to investigate the diversification of mimetic Neotropical butterflies. Despite 10 years since publication, Brower's $(1994,1996)$ mtDNA data for Heliconius butterflies remains the most significant contribution to this field. Our estimates of subspecies divergence dates are largely consistent with Brower's findings, but in contrast we found no evidence that similarly appearing mimetic races were mainly the result of convergent evolution. Brower $(1994,1996)$ found that the Heliconius mtDNA topology largely mirrored the biogeographic distributions, but that there was a lack of concordance between geography and wing pattern. The dissimilarity between Hyposcada anchiala and Heliconius might simply be an artefact of the chosen loci, and given the above concerns that mtDNA might not be a reliable foundation for subsequent inferences, it would be of value to corroborate both data sets with independent nuclear loci. Unfortunately such research is currently hampered as few molecular markers are available which evolve rapidly enough to allow reliable phylogenetic reconstruction of closely related groups of Lepidoptera. This study could also be improved by sequencing additional $H$. anchiala subspecies, but sufficiently preserved samples are typically hard to obtain. It would also be of interest to investigate other species with parallel uplandlowland distribution patterns. Notwithstanding these concerns, it seems likely that differences in ithomiine and heliconiine mimicry evolution reflect genuinely different evolutionary histories. Such differences have previously been reported, for example, in the ithomiine genus Ithomia Hübner, mimicry shifts between species occur rarely (Mallarino et al., 2005), in sharp contrast to Heliconius (Brower, 1996).

Although offering detailed insights into the mechanisms contributing to Neotropical diversification, it is likely that different taxa have experienced highly heterogeneous modes of diversification and thus individual examples are poor at elucidating the general patterns which account for total taxon diversity. Reliable distribution data and robust phylogenies are needed to further investigate geographic patterns of diversification (Willmott et al., 2001). Progress is being made with mtDNA and nuclear loci in the ithomiines, at both the genus level and species level, but, it can be argued that it is the more recently diverged taxa that most accurately retain the signatures of the factors that drove the diversifications. Subspecies within ithomiine species are often at least partly reproductively isolated, for example by mimetic alle- 
giance or habitat adaptations, therefore, to test the predictions of distinct mechanisms of diversification we may need to look closely at subspecies level phylogenies.

In summary, mtDNA sequence data revealed that the diversification of 5 subspecies of $H$. anchiala was more consistent with allopatric divergence than ecological adaptation, and occurred largely during the Pleistocene. Evidence suggests that, at least in this group, the divergent forms here assigned to subspecies are evolving most rapidly in the Amazon basin.

\section{REFERENCES}

Barraclough T.G. \& NeE S. 2001: Phylogenetics and speciation. Trends Ecol. Evol. 16: 391-399.

BECCALONI G. 1997a: Vertical stratification of ithomiine butterfly (Nymphalidae: Ithomiinae) mimicry complexes: the relationship between adult flight height and larval host-plant height. Biol. J. Linn. Soc. 62: 313-341.

BeCCALONI G.W. 1997b: Ecology, natural history and behaviour of ithomiine butterflies and their mimics in Ecuador (Lepidoptera: Nymphalidae: Ithomiinae). Tropic. Lepid. 8: 103-124.

Benson W.W. 1982: Alternative models for infrageneric diversification in the humid tropics: tests with passion vine butterflies. In Prance G.T. (ed.): Biological Diversification in the Tropics. Columbia Univ. Press, New York, pp. 608-640.

BROWER A.V.Z. 1994: Rapid morphological radiation and convergence among races of the butterfly Heliconius erato inferred from patterns of mitochondrial DNA evolution. Proc. Nat. Acad. Sci. USA 91: 6491-6495.

Brower A.V.Z. 1996: Parallel race formation and the evolution of mimicry in Heliconius butterflies: a phylogenetic hypothesis from mitochondrial DNA sequences. Evolution 50: 195-221.

Brower A.V.Z., DeSAlle R. \& Vogler A. 1996: Gene trees, species trees, and systematics. A cladistic perspective. Annu. Rev. Ecol. Syst. 27: 423-450.

Brown K.S. 1979: Ecologia Geográfica e Evolução nas Florestas Neotropicais. Universidade Estadual de Campinas, Campinas, Brazil, $256 \mathrm{pp}$.

BRown K.S. 1982: Historical and ecological factors in the biogeography of aposematic Neotropical butterflies. Am. Zool. 22: 453-471.

Brown K.S. 1987: Biogeography and evolution of neotropical butterflies. In Whitmore T.C. \& Prance G.T. (eds): Biogeography and Quaternary History in Tropical America. Oxford Univ. Press, Oxford, pp. 66-104.

Brown K.S. \& Benson W.W. 1974: Adaptive polymorphism associated with multiple Müllerian mimicry in Heliconius numata (Lepid.: Nymph.). Biotropica 6: 205-228.

ENDLER J.A. 1982: Pleistocene forest refuges: fact or fancy? In Prance G.T. (ed.): Biological Diversification in the Tropics. Columbia Univ. Press, New York, pp. 641-657.

FJELDSÄ J. 1994: Geographical patterns for relict and young species of birds in Africa and South America and implications for conservation priorities. Biodiv. Conserv. 3: 207-226.

Haffer J. 1969: Speciation in Amazonian forest birds. Science 165: $131-137$.
Hall J.P.W. \& Harvey D.J. 2002: The phylogeography of Amazonia revisited: new evidence from riodinid butterflies. Evolution 56: 1489-1497.

HuElSENBECK J.P. \& RonQuist F. 2001: MRBAYES: Bayesian inference of phylogenetic trees. Bioinformatics 17: 754-755.

Jiggins C.D., Naisbit R.E., Coe R.L. \& Mallet J. 2001: Reproductive isolation caused by colour pattern mimicry. Nature (London) 411: 302-305.

Jiggins C.D., Mallarino R., Willmott K.R. \& Bermingham E. XXX: What can phylogenies tell us about speciation? The case of Ithomia (Lepidoptera; Nymphalidae). Submitted to Evolution.

JoRON M. \& MALLET J. 1998: Diversity in mimicry: paradox or paradigm? Trends Ecol. Evol. 13: 461-466.

Joron M., Wynne I.R., Lamas G. \& Mallet J. 1999: Variable selection and the coexistence of multiple mimetic forms of the butterfly Heliconius numata. Evol. Ecol. 13: 721-754.

Lamas G. 2004: Nymphalidae. Ithomiinae. Checklist: Part 4A. Hesperioidea - Papilionoidea. In Heppner J.B. (ed.): Atlas of Neotropical Lepidoptera. Vol. 5A. Association for Tropical Lepidoptera, Scientific Publishers, Gainesville, pp. 172-191.

Maddison W.P. 1997: Gene trees in species trees. System. Biol. 46: 523-536.

Mallarino R., Bermingham E., Willmott K.R., Whinnett A. \& JiGGINS C.D. 2005: Molecular systematics of the butterfly genus Ithomia (Lepidoptera: Ithomiinae): a composite phylogenetic hypothesis based on seven genes. Molec. Phylogen. Evol. 34: 625-644.

MÜLLER F. 1879: Ituna and Thyridia; a remarkable case of mimicry in butterflies. Trans. Entomol. Soc. Lond. 1879: xx-xxix.

Posada N.M. \& CRANDAll K.A. 1998: MODELTEST: testing the model of DNA substitution. Bioinformatics 14: 817-818.

RobBins R.K. \& OpLER P.A. 1996: Butterfly diversity and a preliminary comparison with bird and mammal diversity. In Reaka-Kudla M.R., Wilson D.E. \& Wilson E.O. (eds): Biodiversity II. Understanding and Protecting our Biological Resources. National Academy of Sciences, Washington, DC, pp. 69-82

Sheppard P.M., Turner J.R.G., Brown K.S., Benson W.W. \& SINGER M.C. 1985: Genetics and the evolution of muellerian mimicry in Heliconius butterflies. Phil. Trans. R. Soc. Lond. (Ser. B, Biol. Sci.) 308: 433-613.

Simon C., Frati F., Beckenbach A., Crespi B., Liu H. \& Flook P. 1994: Evolution, weighting, and phylogenetic utility of mitochondrial gene sequences and a compilation of conserved polymerase chain reaction primers. Ann. Entomol. Soc. Am. 87: 651-702.

Swofford D.L. 2000 PAUP*: Phylogenetic Analysis Using Parsiomony (*and Other Methods). Sunderland, Mass. Sinauer Associates.

Willmott K.R. 2001: The Genus Adelpha: Its Systematics, Biology and Biogeography. Scientific Publishers, Gainesville, FL, viii + 322 pp.

Willmott K., Hall J.P.W. \& Lamas G. 2001: Systematics of Hypanartia (Lepidoptera: Nymphalidae: Nymphalinae), with a test for geographical speciation mechanisms in the Andes. Syst. Entomol. 26: 369-399.

Received April 4, 2005; revised and accepted June 6, 2005 